\title{
Consequences of soil attributes on the productivity and eucalypt drought response in two climate types in Brazil
}

\author{
Consequências dos atributos dos solos na produtividade e reposta à seca do \\ eucalipto em dois tipos de clima no Brasil
}

\author{
Vinicius Evangelista Silva ${ }^{\mathrm{I}}$, Salatier Buzetti" ${ }^{\mathrm{II}}$, Jean-Paul Laclau ${ }^{\mathrm{III}}$, \\ Rafael Montanari" ${ }^{\mathrm{II}}$, Alan Rodrigo Panosso ${ }^{\mathrm{IV}}$, \\ Sharlles Christian Moreira Dias ${ }^{\mathrm{v}}$, João Flávio da Silva ${ }^{\mathrm{v}}$
}

\begin{abstract}
The present study aimed to evaluate the correlations between productivity and eucalyptus drought (DR) response between soil attributes in two distinct climatic types in Brazil. For this, 24 experiments were installed in Brazil with four common clones in all the experiments to obtain strong edaphoclimatic contrasts, and, thus, to measure the productivity and the response to drought and to describe its relationship with the attributes of the soils. Two climatic groups were evaluated: Wet (precipitation rate: evapotranspiration between 1.0 to 2.5) and Sub-Humid (precipitation rate: evapotranspiration between 0.5 to 1.0). The attributes of the evaluated soils were: Sand, Silt, Clay, organic matter (O.M.), cation exchange capacity (CEC). For sites located in the wet climate class, CVWB correlated negatively with O.M. and clay, and positively with the sand. For DR, the correlations were observed for the Sub-Humid climate for the CEC and Sand variables, and for the Humid climate, no correlations were observed between the attributes of soils with DR.
\end{abstract}

Keywords: Climate; Edaphoclimatic groups; Tolerance to forest aridity; Soil quality

\section{Resumo}

O objetivo do presente trabalho foi avaliar as correlações entre produtividade e resposta à seca (RS) do eucalipto entre os atributos do solo em dois tipos climáticos distintos no Brasil. Para isto, foram instalados 24 experimentos no Brasil com 4 clones comuns em todos os experimentos para obter fortes contrastes edafoclimáticos, e, desse modo, mensurar a produtividade e a reposta à seca e descrever as suas relações com os atributos de solos. Foram avaliados dois grupos climáticos: Úmido (relação precipitação: evapotranspiração entre 1,0 a 2,5) e Subúmido (relação precipitação: evapotranspiração entre 0,5 a 1,0). Os atributos dos solos avaliados foram: Areia, Silte, Argila, matéria orgânica (M.O.), capacidade de troca catiônica (CTC). Para os sítios localizados na classe climática Úmida, o VCCC correlacionouse negativamente com a M.O. e argila, e positivamente com a Areia. Para a RS, as correlações foram observadas para clima Subúmido para as variáveis CTC e Areia, e para o clima Úmido, não foram observadas correlações entre os atributos de solos com a RS.

Palavras-chave: Clima; Grupos edafoclimáticos; Tolerância à aridez florestal; Qualidade do solo

Engenheiro Florestal, Dr., VIMEF Soluções Florestais, Universidade Estadual Paulista, Av. Brasil Sul, 56, Centro, CEP 15385-000, Ilha Solteira (SP), Brasil. viniciusesilva@yahoo.com.br (ORCID: 0000-0002-9422-7657)

II Engenheiro Agrônomo, Dr., Professor Titular/ Adjunto do Departamento de Fitossanidade, Engenharia Rural e Solos, Faculdade de Engenharia de Ilha Solteira, Universidade Estadual Paulista, Av. Brasil, 56, CEP 15385-000, Ilha Solteira (SP), Brasil. sbuzetti@agr.feis.unesp.br (ORCID: 00000003- 2569-4750) / r.montanari@unesp.br (ORCID: 0000-0002-3557-2362)

III Engenheiro Florestal, Dr., Eco\&Sols, Université de Montpellier, CIRAD, INRA, IRD, Montpellier SupAgro, 389 Avenue Agropolis, 34980, Montferrier-sur-Lez, Montpellier, Franca. jean-paul.laclau@cirad.fr (ORCID: 0000-0002-2506-214X)

IV Engenheiro Agrônomo, Dr., Professor Assistente Doutor do Departamento de Ciências Exatas, Faculdade de Ciências Agrárias e Veterinárias, câmpus de Jaboticabal, Universidade Estadual Paulista, Via de Acesso Prof. Paulo Donato Castellane, s/n, CEP 14884-900, Jaboticabal (SP), Brasil. alan.panosso@unesp.br (ORCID: 0000-0001-9916-1696)

Engenheiro Florestal, Dr., Eldorado Brasil Celulose, BR-158, Km 231, S/N, Fazenda Santa Vera, Três Lagoas (MS), CEP 79641-300, Brasil. sharlles. dias@eldoradobrasil.com.br (ORCID: 0000-0002-6716-7142) / joao.sila@eldoradobrasil.com.br (ORCID: 0000-0002-5745-7541) 


\section{Introduction}

High rates of growth depend on the application of results of the research programs in genetic improvement (RESENDE et al., 2012) and silvicultural practices, including site preparation, fertilization, spacing and weed control (GONÇALVES et al., 2013), the effects of soils on the eucalyptus productivity (GONÇALVES et al., 2012). The climate strongly influences the growth of planted forests of Eucalyptus; a doubling of precipitation from $800 \mathrm{~mm} \mathrm{yr}^{-1}$ to 1600 $\mathrm{mm} \mathrm{yr}^{-1}$ along a $100 \mathrm{~km}$ gradient in Bahia state led to a 3-fold increase in wood growth (from 10 $\mathrm{Mg} \mathrm{ha}^{-1} \mathrm{yr}^{-1}$ to $30 \mathrm{Mg} \mathrm{ha}^{-1} \mathrm{yr}^{-1}$ (STAPE; RYAN; BINKLEY, 2004). Variation of wood productivity in the Eucalyptus grandis plantations, characterized in six soil classes, with total amplitude ranging from 26 to $52 \mathrm{~m}^{3} \mathrm{ha}^{-1} \mathrm{yr}^{-1}$ (2-fold), but in only one place (GONÇALVES et al., 2013). However, regional-scale studies addressing the soils and climate are still poorly studied and require further grounding by soil scientists (VOLKOFF et al., 2012)

One of the efficient ways to reduce the cost of wood is to increase forest productivity, and one of the strategies to achieve this goal is to know the main environmental stresses to Eucalyptus that are factors that reduce productivity. Among these, two stand out due to their association with the new forest frontiers, namely: i) Water stress, mainly in the central-west, north, northeast, and part of southeastern Brazil; and ii) Thermal stress related to high temperatures (above $36{ }^{\circ} \mathrm{C}$ ) in tropical Brazil, or at low temperatures (below $5{ }^{\circ} \mathrm{C}$ ) in southern Brazil. Thus, the cooperative program on the Tolerance of Eucalyptus Clones to Water and Thermal Stresses (TECHS) was proposed through a very robust experimental network installed in Brazil and Uruguay.

A large scientific effort is made to isolate and quantify these forest production factors (STAPE; RYAN; BINKLEY, 2004; GONÇALVES et al., 2012). But sometimes it becomes difficult and complex to separate them, due to the intrinsic spatial and temporal confounding of these factors and forest productivity (STAPE et al., 2010). Since all the TECHS experiments were planted at the same time, this temporal confounding is reduced, and the spatial question is being very well evaluated because the TECHS are located in 24 sites in Brazil.

Besides, the global climate change factor has considerably influenced the crop productivity through increasing global average temperature, and evapotranspiration and the water demand of eucalyptus (ASSAD et al., 2004). In the context of this work, the TECHS discusses the climatic factors (BINKLEY et al., 2017), however, the sensitivity of the productivity of the clones to the different soil characteristics in the respective climatic conditions has not yet been considered in this experiment. That is, knowing the physical-chemical characteristics of the soils, it becomes possible to understand some soil-climate relations for different clones.

Thus, the present study aimed to evaluate the interactions between productivity, response to the drought of eucalyptus and the attributes of the Soils in Brazil (tropical and subtropical) in sites with two types of climate: Wet and Sub-Humid.

\section{Material and methods}

A group of breeders to be deployed at all the TECHS sites defined a group of 18 Eucalyptus clones. These clones represented the different genetic materials in use in Brazil today, but with different species characteristics, susceptibility to water and thermal stresses. The diversity of eco-physiological behaviors within appropriate levels of productivity was sought here. All measurements and information from these clones were shared among the companies participating in the TECHS to define the pool of clones to be used in the TECHS.

Due to the great climatic amplitude of Brazil, the clones were divided into four groups: a) Tropical Clones and of Humid regions (Type U); b) Tropical clones and drier regions (Type S); c) Clones from colder subtropical regions (Type F); and d) Intermediate clones and more Plastics (Type P). In this work, only four plastic clones planted in the TECHS were used and were indicated for the experiment because they are clones widely planted operationally in the forest 
companies in Brazil, namely: A1, C3, K2, and Q8. The main genetic characteristics and some climatic parameters of the clones used in these studies are presented, according to data reported by Flores et al. (2016) and Binkley et al. (2017) (Table 1).

Table 1 - The four genotypes of Eucalyptus in the network of the TECHS experiments, the climate of origin in which each clone was developed during breeding programs and where they were selected

Tabela 1 - Os quatro genótipos de Eucalyptus na rede de experimentos do TECHS, clima de origem em que cada clone foi desenvolvido durante os programas de melhoramento e onde foram selecionados

\begin{tabular}{|c|c|c|c|c|c|c|}
\hline Clones & Genotype & $\begin{array}{c}\text { Average } \\
\text { Annual } \\
\text { Temperature } \\
\left({ }^{\circ} \mathrm{C}\right)\end{array}$ & $\begin{array}{l}\text { Rainfall } \\
(\mathbf{m m})\end{array}$ & Climate & Natural Occurrence & $\begin{array}{l}\text { The climate } \\
\text { in which } \\
\text { the clone } \\
\text { was selected }\end{array}$ \\
\hline A1 & $\begin{array}{l}\text { Eucalyptus } \\
\text { urophylla }\end{array}$ & $16-27$ & $\begin{array}{l}1000- \\
2000\end{array}$ & $\begin{array}{l}\text { Tropical } \\
\text { and } \\
\text { subtropical }\end{array}$ & $\begin{array}{l}\text { Predominantly Aw, and to a } \\
\text { lesser extent in climates Af, } \\
\text { Am, Cwa and Cwb }\end{array}$ & Cwa \\
\hline $\mathrm{C}^{1}$ & $\begin{array}{l}\text { Eucalyptus grandis } \\
\text { x Eucalyptus } \\
\text { camaldulensis }\end{array}$ & $\begin{array}{l}15-22 \text { and } \\
16-27\end{array}$ & $\begin{array}{l}800-2000 \\
\text { and } 500- \\
1500\end{array}$ & $\begin{array}{l}\text { Tropical } \\
\text { and } \\
\text { subtropical }\end{array}$ & $\begin{array}{c}\text { Eucalyptus grandis } \\
\text {-Predominantly Cfa, and to } \\
\text { a lesser extent in climates } \\
\text { Cwa, Cwb, and Cfb. } \\
\text { Eucalyptus camaldulensis } \\
\text { - predominantly Aw, to a } \\
\text { lesser extent As, Cwa, Cwb }\end{array}$ & As \\
\hline $\mathbf{K} 2$ & Eucalyptus saligna & $13-18$ & $900-1400$ & Subtropical & $\begin{array}{l}\text { Predominantly Cfb, Cfa, } \\
\text { Cwb }\end{array}$ & $\mathrm{Cfb}$ \\
\hline Q8 & Eucalyptus grandis & $15-22$ & $800-2000$ & Subtropical & $\begin{array}{l}\text { Predominantly Cfa, and to } \\
\text { a lesser extent in climates } \\
\text { Cwa, Cwb, and Cfb. }\end{array}$ & Af \\
\hline
\end{tabular}

Source: Authors (2018)

On what: A1, C3, K2, Q8 = commercially planted eucalyptus clones in Brazil; ${ }^{1}$ Clone C3 is a hybrid of Eucalyptus grandis $\mathrm{x}$ Eucalyptus camaldulensis, and thus the climatic parameters of the two species have been described.

Two composite samples were collected for each site, with layers 0-20 and 20-40 cm depth (Table 2). Each composite sample represented 20 simple soil samples collected systematically in a zigzag path throughout the entire experimental area. Soil $\mathrm{pH}$ was determined in water $(\mathrm{pH})$, in a ratio of 1:2.5 (soil: water). Organic matter (O.M.) determined by the sodium bichromate digestion method (RAIJ; QUAGGIO; CANTARELLA, 1987). Ca, $\mathrm{Mg}$ and Al extracted with $1 \mathrm{~mol} \mathrm{~L}^{-1} \mathrm{KCl}$ and analyzed by titulometry analysis (EMBRAPA, 1997). $\mathrm{P}$ and $\mathrm{K}$ available through an anion exchange resin extractor and determined, respectively, by colorimetry and flame photometry. The potential acidity $(\mathrm{H}+\mathrm{Al})$ was determined indirectly through SMP solution and quantified in potentiometer (QUAGGIO; RAIJ; MALAVOLTA, 1985). The saturation by bases (V) and by aluminum (m), Cation Exchange Capacity (CEC), Base Sum (BS) were determined indirectly from the values of potential acidity, exchangeable bases and exchangeable aluminum, as described by Ribeiro, Guimarães and Venegas (1999). Soil micronutrients $\mathrm{Cu}, \mathrm{Zn}, \mathrm{Mn}, \mathrm{Fe}$, extracted by Mehlich-1; boron (B) by weighing $20 \mathrm{~g}$ of soil with $40 \mathrm{ml}$ of deionized water, heated to boiling under reflux for five minutes and, after cooling the solution, three drops of $0.1 \mathrm{~mol} \mathrm{~L}^{-1} \mathrm{CaCl}_{2}$ and filtered the material for the boron determinations (SILVA; FERREIRA, 1998). Concerning the 
physical analysis, a granulometric analysis was performed by the densimeter method (EMBRAPA, 1997), and the samples were dispersed with sodium hexametaphosphate, and the clay, silt and sand granulometry were considered. All the soil attributes result presented in this work refer to the average of the layers $0-20$ and $20-40 \mathrm{~cm}$.

Table 2 - History of land use and occupation before the installation of the TECHS

Tabela 2 - Histórico de uso e ocupação do solo antes da instalação do TECHS

\begin{tabular}{|c|c|c|c|c|c|c|c|c|c|c|c|}
\hline TECHS & County & State & $\begin{array}{c}\text { Order of } \\
\text { soil }\end{array}$ & pH & O.M & CEC & Clay & Silt & Sand & $\begin{array}{c}\text { Species / } \\
\text { Vegetation } \\
\text { Prior to } \\
\text { Experiment }\end{array}$ & $\begin{array}{c}\text { Years } \\
\text { of Soil } \\
\text { Occupation }\end{array}$ \\
\hline 2 & Arapoti & PR & Oxisol & 4.1 & 35.5 & 92.4 & 70.8 & 21.8 & 7.3 & Pinus & 40 years \\
\hline 4 & $\begin{array}{c}\text { Belo } \\
\text { Oriente }\end{array}$ & MG & Oxisol & 4.1 & 35.0 & 61.7 & 58.9 & 10.4 & 30.6 & Eucalyptus & 40 years \\
\hline 5 & Guanhães & MG & Oxisol & 3.9 & 41.0 & 92.3 & 43.7 & 13.4 & 42.9 & Eucalyptus & 30 years \\
\hline 6 & $\begin{array}{l}\text { Eldorado } \\
\text { do } \\
\text { Sul }\end{array}$ & RS & Ultisol & 3.7 & 25.0 & 128.0 & 27.4 & 18.6 & 54.1 & Eucalyptus & 14 years \\
\hline 7 & Rio Verde & $\mathrm{GO}$ & Entisol & 4.5 & 19.0 & 35.8 & 6.3 & 4.5 & 89.2 & Eucalyptus & 20 years \\
\hline 9 & $\begin{array}{c}\text { Estrela } \\
\text { do } \\
\text { Sul }\end{array}$ & MG & Oxisol & 3.9 & 43.0 & 88.8 & 80.0 & 9.0 & 11.1 & Pinus & 35 years \\
\hline 10 & Botucatu & SP & Oxisol & 4.3 & 30.0 & 66.7 & 19.6 & 9.4 & 71.0 & Eucalyptus & - \\
\hline 11 & $\begin{array}{c}\text { Chapadão } \\
\text { do } \\
\text { Sul }\end{array}$ & MS & Oxisol & 4.3 & 23.5 & 55.0 & 15.1 & 9.0 & 75.9 & Pasture & - \\
\hline 12 & Aracruz & ES & Oxisol & 4.0 & 18.0 & 40.7 & 30.2 & 12.1 & 57.7 & Eucalyptus & 20 years \\
\hline 13 & $\begin{array}{c}\text { Três } \\
\text { Lagoas }\end{array}$ & MS & Oxisol & 4.0 & 11.0 & 62.7 & 14.0 & 8.7 & 77.3 & Pasture & - \\
\hline 14 & Inocência & MS & Entisol & 4.1 & 10.5 & 64.8 & 10.0 & 8.4 & 81.6 & Pasture & - \\
\hline 15 & $\begin{array}{l}\text { Brejinho } \\
\text { do } \\
\text { Nazaré }\end{array}$ & TO & Entisol & 4.2 & 7.5 & 64.6 & 10.0 & 8.0 & 82.0 & Cerrado & - \\
\hline 17 & $\begin{array}{c}\text { Três } \\
\text { Marias }\end{array}$ & MG & Oxisol & 4.1 & 15.5 & 47.4 & 13.8 & 5.4 & 80.8 & Eucalyptus & 40 years \\
\hline 19 & Peixe & TO & Oxisol & 4.0 & 13.5 & 77.5 & 20.2 & 14.1 & 65.8 & Pasture & 5 years \\
\hline 20 & $\begin{array}{l}\text { Mogi- } \\
\text { Guaçu }\end{array}$ & SP & Oxisol & 4.1 & 34.0 & 97.2 & 41.3 & 16.3 & 42.4 & Eucalyptus & 45 years \\
\hline 22 & $\begin{array}{c}\text { Telemaco } \\
\text { Borba }\end{array}$ & PR & Oxisol & 4.0 & 52.0 & 183.8 & 55.8 & 22.7 & 21.5 & Eucalyptus & 8 years \\
\hline 23 & $\begin{array}{c}\text { Otacílio } \\
\text { Costa }\end{array}$ & SC & Inceptisol & 3.9 & 44.5 & 338.0 & 42.8 & 27.7 & 29.4 & Pinus & 16 years \\
\hline 24 & Borebi & SP & Entisol & 4.6 & 12.0 & 104.5 & 7.5 & 3.2 & 89.3 & Eucalyptus & 14 years \\
\hline
\end{tabular}


Table 2 - Conclusion ...

Tabela 2 - Conclusão ...

\begin{tabular}{|c|c|c|c|c|c|c|c|c|c|c|c|}
\hline TECHS & County & State & $\begin{array}{c}\text { Order of } \\
\text { soil }\end{array}$ & $\mathbf{p H}$ & O.M & CEC & Clay & Silt & Sand & $\begin{array}{c}\text { Species / } \\
\text { Vegetation } \\
\text { Prior to } \\
\text { Experiment }\end{array}$ & $\begin{array}{c}\text { Years } \\
\text { of Soil } \\
\text { Occupation }\end{array}$ \\
\hline 26 & $\begin{array}{c}\text { Coração } \\
\text { de } \\
\text { Jesus }\end{array}$ & MG & Oxisol & 3.9 & 32.0 & 120.6 & 34.6 & 6.0 & 59.4 & Cerrado & - \\
\hline 27 & $\begin{array}{c}\text { Antônio } \\
\text { Olinto }\end{array}$ & PR & Ultisol & 3.9 & 25.5 & 141.5 & 13.9 & 5.2 & 80.9 & Pinus & 16 years \\
\hline 28 & Três Barras & SC & Oxisol & 3.8 & 51.0 & 291.1 & 60.2 & 23.6 & 16.2 & Eucalyptus & 12 years \\
\hline 29 & $\begin{array}{l}\text { Urbano } \\
\text { Santos }\end{array}$ & MA & Entisol & 4.1 & 16.0 & 91.4 & 8.8 & 4.6 & 86.7 & Cerrado & - \\
\hline 30 & Bocaiúva & MG & Oxisol & 3.9 & 47.5 & 209.1 & 76.4 & 14.1 & 9.6 & Eucalyptus & 20 years \\
\hline 33 & Buri & SP & Oxisol & 4.1 & 27.9 & 111.1 & 33.1 & 24.0 & 42.9 & Eucalyptus & 20 years \\
\hline
\end{tabular}

Source: Authors (2018)

On what: TECHS = number of the techs site that identifies where it was planted; MG = state of Minas Gerais; PR = state of Paraná; RS = state of Rio Grande do Sul; GO = state of Góias; SP =state of São Paulo; MS = state of Mato Grosso do Sul; TO= state of Tocantins; SC = state of Santa Catarina; MA = state of Maranhão; $\mathrm{pH}$ in water = hydrogen potential; O.M. = Organic matter $(\mathrm{g} \mathrm{dm}-3) ; \mathrm{CEC}=$ Cation Exchange Capacity $\left(\mathrm{mmolc} / \mathrm{dm}^{-3}\right)$; Clay = soil clay content $(\%)$; Silt = soil silt content $(\%) ;$ Sand $=$ soil sand content $(\%)$.

The plantations were carried out in areas of reforestation (Eucalyptus sp. and Pinus sp.), grass, as well as in areas of Cerrado (Table 2). The number of rotations ranged from 1 st to 5 th forest rotation, and the average forest rotation duration was between 6-7 years. The soil preparation was the operational one of the Brazilian forest companies, which its average ranged from 40 to $50 \mathrm{~cm}$ deep, and lateral squatting of $70 \mathrm{~cm}$, using the subsoiler/scarifier for soil preparation. This information will be important to justify the soil attributes contents, as well as the yield and drought response results presented in this study.

Additionally, the history of soil use and occupation before the TECHS experiment was presented. It is observed that the areas of plantations in Brazil range from very new areas to areas with 45 years of Eucalyptus plantations. These data to portray well the reality of Brazil between traditional planting areas with extensive knowledge of forestry as well as high technological level used in wood production (e.g TECHS 20 as a traditional site for forestry areas), to silvicultural frontier areas with limited knowledge in terms of soil and climatic conditions (e.g TECHS 13 as a forestry frontier site).

The order of soil with the highest occurrence among the experiments was Ferralsol (67\%), followed by Arenosol (21\%), Nitisol (8\%), and Cambisol (4\%). According to the most up-to-date mapping of soils in Brazil (SANTOS et al., 2011), Oxisols occur in approximately 31\% of Brazilian territory, and this shows that forest areas are generally shifted to marginal areas with the lowest natural fertility and highly weathered but deep soils, which is the case with Oxisols (Figure 1). 


\section{Figure 1 - Map and location of the TECHS sites in Brazil}

Figura 1 - Mapa e localização dos sítios da TECHS no Brasil

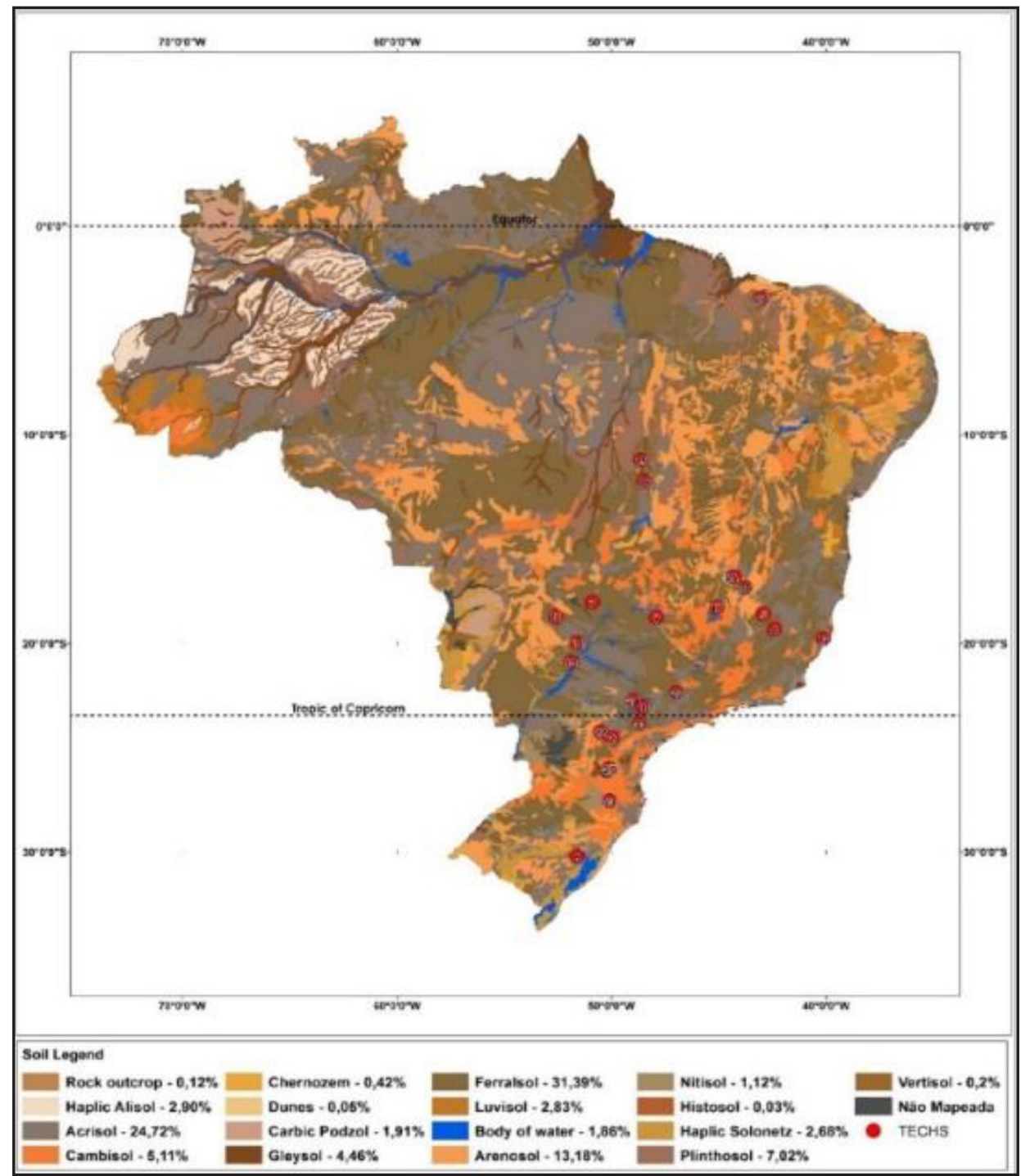

Source: Silva et al. (2019)

The fertilizers used previously were the same as those used in forestry companies, usually composed of NPK $+\mathrm{S}$ and micronutrients in the fertilization of the planting, liming in the total area without incorporation, and one or two cover fertilizations, ending the cover fertilization up to a maximum of 18 months after planting.

Each clone was planted in a single plot, with 8 Lines $\times 30$ trees (plot size $24 \times 90 \mathrm{~m}-2160$ $\mathrm{m}^{2}$ ), with trees at a square spacing of $3 \times 3 \mathrm{~m}$ (1111 ha- $\mathrm{h}^{-1}$ trees). One edge of each plot had 5 rows (each one with 8 trees) available for destructive sampling throughout the project.

The diameter at breast height $(\mathrm{DBH})$ and the total height of the 80 central trees of the plots with rainfall and rainfall exclusion $(70 \%$ of the total rainfall) were measured, as shown in Figure 2. 
Figure 2 - Sketch of a complete replication of the TECHS water stress test with the 4 clones. Note the central drainage line. Dimensions of $144 \mathrm{~m}$ x $180 \mathrm{~m}$ (12 lines per 60 plants, $3 \mathrm{~m} \times 3 \mathrm{~m})$

Figura 2 - Esboço de uma repetição completa do teste de estresse hídrico do TECHS com os 4 clones. A seta representa a linha de drenagem central. Dimensões de $144 \mathrm{~m}$ x $180 \mathrm{~m}$ (12 linhas por 60 plantas, $3 \mathrm{~m} \times 3 \mathrm{~m}$ )

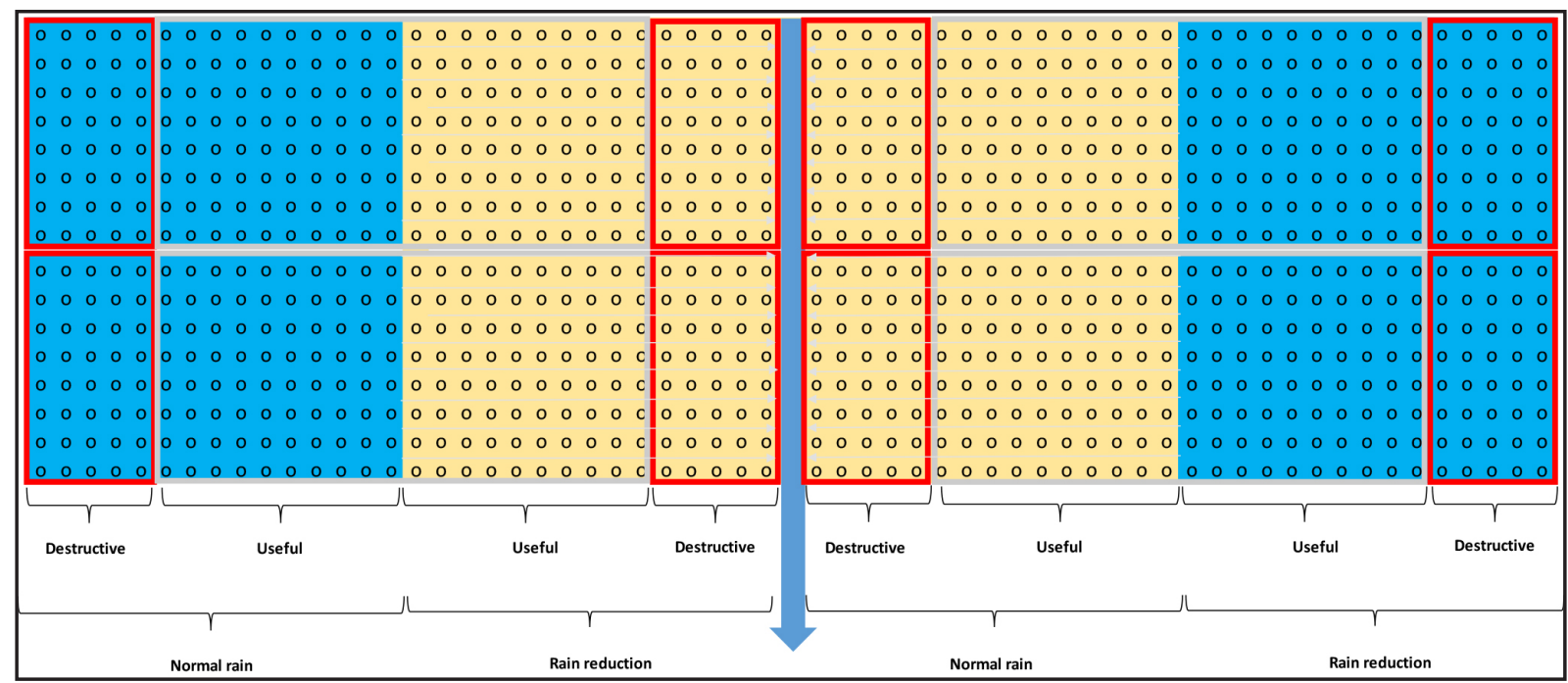

Source: Silva et al. (2019)

For the manipulation of water availability, the "rainfall exclusion" was used in the four clones/plots studied. The technique is based on a cover made between the planting lines covering $30 \%$ of the plot surface area, thus estimating a reduction of the rainfall reaching the soil to $70 \%$ of the total precipitation. The cover was made one year after planting the trees, with Eucalyptus sp. poles and plastic tarps, with a slope that takes water out of the plot.

The sites presented a variation of about $10^{\circ} \mathrm{C}\left(17.1-27.5^{\circ} \mathrm{C}\right)$ between the colder and hottest sites (Table 3). The average annual rainfall ranged from 609 to $1525 \mathrm{~mm}$. Likewise, climatic types ranged from the tropical climate with dry summer and the driest month with rainfall lower than $60 \mathrm{~mm}$, to Cwb climate with a subtropical climate with moderate summer temperature and rainfall above $40 \mathrm{~mm}$ in the driest month (ALVARES et al., 2013).

The Aridity Index was developed by Thornthwaite (1948) and supplemented by Penman (1953), as follows:

$$
\text { Aridity Index }=\frac{P(\mathrm{~mm})}{\operatorname{ETP}(\mathrm{mm})}
$$

Wherein:

$\mathrm{P}(\mathrm{mm})=$ annual average of rainfall,

ETP $(\mathrm{mm})=$ annual average of potential evapotranspiration calculated by the Penman-Monteith method using the storage capacity of soil water at the specific site 
Silva, V. E.; Buzetti, S.; Laclau, J. P.; Montanari, R.;

Table 3 - Climatic description for 24 of the TECHS sites for the growth period (0-48 months) presented in this article

Tabela 3 - Descrição climática de 24 dos sítios do TECHS para o período de crescimento (0 a 48 meses) apresentados neste artigo

\begin{tabular}{|c|c|c|c|c|c|c|c|c|c|c|c|c|c|}
\hline TECHS & Lat & Long & Att & County & State & $\begin{array}{l}\text { Tavr } \\
{ }^{\circ} \mathrm{C}\end{array}$ & $\begin{array}{c}\mathbf{P} \\
(\mathbf{m m})\end{array}$ & $\begin{array}{l}\text { ETP } \\
(\mathbf{m m})\end{array}$ & $\begin{array}{l}\text { ETR } \\
(\mathbf{m m})\end{array}$ & $\begin{array}{l}\text { DEF } \\
(\mathbf{m m})\end{array}$ & Class & $\begin{array}{c}\text { Koppen } \\
\text { Climate } \\
\text { Classification }\end{array}$ & $\begin{array}{l}\text { Aridity } \\
\text { Index }\end{array}$ \\
\hline 2 & -24.5 & -50.0 & 770 & Arapoti & PR & 18.4 & 1436 & 569 & 562 & 7 & Subtropical & Cwb & $\begin{array}{l}\text { Super } \\
\text { humid }\end{array}$ \\
\hline 4 & -19.3 & -42.4 & 243 & $\begin{array}{c}\text { Belo } \\
\text { Oriente }\end{array}$ & MG & 23.0 & 1065 & 1002 & 828 & 174 & Tropical & Aw & Humid \\
\hline 5 & -18.6 & -42.9 & 873 & Guanhães & MG & 21.0 & 1013 & 796 & 704 & 92 & Tropical & As & Humid \\
\hline 6 & -30.2 & -51.6 & 150 & $\begin{array}{c}\text { Eldorado } \\
\text { do Sul }\end{array}$ & RS & 20.6 & 1446 & 742 & 734 & 8 & Subtropical & $\mathrm{Cfa}$ & Humid \\
\hline 7 & -18.0 & -50.9 & 681 & Rio Verde & $\mathrm{GO}$ & 23.2 & 1319 & 1036 & 724 & 312 & Tropical & Aw & Humid \\
\hline 9 & -18.7 & -47.9 & 969 & $\begin{array}{l}\text { Estrela } \\
\text { do Sul }\end{array}$ & MG & 23.5 & 1334 & 1067 & 928 & 139 & Tropical & Aw & Humid \\
\hline 10 & -23.0 & -48.5 & 869 & Botucatu & SP & 21.4 & 1332 & 842 & 783 & 58 & Tropical & Aw & Humid \\
\hline 11 & -18.7 & -52.6 & 783 & $\begin{array}{c}\text { Chapadão } \\
\text { do Sul }\end{array}$ & MS & 22.8 & 1154 & 983 & 780 & 203 & Tropical & Aw & Humid \\
\hline 12 & -19.8 & -40.1 & 36 & Aracruz & ES & 24.8 & 830 & 1218 & 728 & 490 & Tropical & Aw & $\begin{array}{l}\text { Sub- } \\
\text { Humid }\end{array}$ \\
\hline 13 & -20.9 & -51.9 & 361 & $\begin{array}{c}\text { Três } \\
\text { Lagoas }\end{array}$ & MS & 25.3 & 1123 & 1325 & 1027 & 298 & Tropical & Aw & $\begin{array}{l}\text { Sub- } \\
\text { Humid }\end{array}$ \\
\hline 14 & -20.0 & -51.6 & 480 & Inocência & MS & 24.3 & 1026 & 1188 & 916 & 272 & Tropical & Aw & $\begin{array}{l}\text { Sub- } \\
\text { Humid }\end{array}$ \\
\hline 15 & -11.2 & -48.6 & 255 & $\begin{array}{c}\text { Brejinho } \\
\text { do } \\
\text { Nazaré }\end{array}$ & $\mathrm{TO}$ & 26.2 & 1189 & 1415 & 849 & 566 & Tropical & $\mathrm{Aw}$ & $\begin{array}{l}\text { Sub- } \\
\text { Humid }\end{array}$ \\
\hline 17 & -18.3 & -45.1 & 806 & $\begin{array}{c}\text { Três } \\
\text { Marias }\end{array}$ & $\mathrm{MG}$ & 22.4 & 921 & 941 & 652 & 289 & Tropical & As & $\begin{array}{c}\text { Sub- } \\
\text { Humid }\end{array}$ \\
\hline 19 & -12.2 & -48.5 & 255 & Peixe & TO & 26.7 & 987 & 1495 & 820 & 675 & Tropical & As & $\begin{array}{c}\text { Sub- } \\
\text { Humid }\end{array}$ \\
\hline 20 & -22.4 & -47.0 & 633 & $\begin{array}{l}\text { Mogi } \\
\text { Guaçu }\end{array}$ & SP & 22.3 & 1255 & 942 & 867 & 75 & Tropical & Aw & Humid \\
\hline 22 & -24.2 & -50.5 & 888 & $\begin{array}{c}\text { Telêmaco } \\
\text { Borba }\end{array}$ & PR & 17.8 & 1436 & 569 & 561 & 7 & Subtropical & Cwb & $\begin{array}{l}\text { Super } \\
\text { humid }\end{array}$ \\
\hline 23 & -27.5 & -50.1 & 870 & $\begin{array}{c}\text { Otacílio } \\
\text { Costa }\end{array}$ & SC & 17.1 & 1525 & 481 & 476 & 5 & Subtropical & $\mathrm{Cfa}$ & $\begin{array}{l}\text { Super } \\
\text { humid }\end{array}$ \\
\hline 24 & -22.7 & -49.0 & 656 & Borebi & SP & 22.0 & 1116 & 908 & 800 & 109 & Tropical & Aw & Humid \\
\hline 26 & -16.8 & -44.3 & 926 & $\begin{array}{l}\text { Coração } \\
\text { de Jesus }\end{array}$ & MG & 24.4 & 609 & 1179 & 496 & 683 & Tropical & As & $\begin{array}{c}\text { Sub- } \\
\text { Humid }\end{array}$ \\
\hline 27 & -26.0 & -50.1 & 916 & $\begin{array}{c}\text { Antônio } \\
\text { Olinto }\end{array}$ & PR & 17.8 & 1506 & 538 & 537 & 1 & Subtropical & $\mathrm{Cfa}$ & $\begin{array}{l}\text { Super } \\
\text { humid }\end{array}$ \\
\hline
\end{tabular}


Table 3 - Conclusion ...

Tabela 3 - Conclusão ...

\begin{tabular}{|c|c|c|c|c|c|c|c|c|c|c|c|c|c|}
\hline TECHS & Lat & Long & Att & County & State & $\begin{array}{c}\text { Tavr } \\
{ }^{\circ} \mathrm{C}\end{array}$ & $\begin{array}{c}\mathbf{P} \\
(\mathbf{m m})\end{array}$ & $\begin{array}{l}\text { ETP } \\
(\mathbf{m m})\end{array}$ & $\begin{array}{l}\text { ETR } \\
(\mathbf{m m})\end{array}$ & $\begin{array}{l}\text { DEF } \\
(\mathbf{m m})\end{array}$ & Class & $\begin{array}{c}\text { Koppen } \\
\text { Climate } \\
\text { Classification }\end{array}$ & $\begin{array}{c}\text { Aridity } \\
\text { Index }\end{array}$ \\
\hline 28 & -26.1 & -50.2 & 812 & $\begin{array}{l}\text { Três } \\
\text { Barras }\end{array}$ & SC & 17.6 & 993 & 518 & 470 & 48 & Subtropical & Cfa & Humid \\
\hline 29 & -3.4 & -43.1 & 81 & $\begin{array}{l}\text { Urbano } \\
\text { Santos }\end{array}$ & MA & 27.5 & 878 & 1492 & 656 & 836 & Tropical & $\mathrm{Aw}$ & $\begin{array}{l}\text { Sub- } \\
\text { Humid }\end{array}$ \\
\hline 30 & -17.3 & -43.8 & 848 & Bocaiuva & MG & 24.4 & 609 & 1179 & 570 & 609 & Tropical & As & $\begin{array}{l}\text { Sub- } \\
\text { Humid }\end{array}$ \\
\hline 33 & -23.9 & -48.7 & 695 & Buri & SP & 20.0 & 1196 & 662 & 645 & 17 & Subtropical & Cwb & Humid \\
\hline
\end{tabular}

Source: Authors (2018)

On what: TECHS = number of the techs site that identifies where it was planted; Lat = latitude geographic site; Long $=$ longitude geographic site; Alt = altitude in relation to the sea level; Tavr ${ }^{\circ} \mathrm{C}=$ temperature annual average, $\mathrm{P}(\mathrm{mm})$ $=$ rainfall annual average, ETP $(\mathrm{mm})=$ annual average of potential evapotranspiration calculated by the PenmanMonteith method using the storage capacity of the soil water at the specific site, ETR $(\mathrm{mm})=$ annual average of real evapotranspiration, DEF $(\mathrm{mm})=$ annual average of water deficit using the storage capacity of the water in the soil of a specific site; Class $=$ Tropical sites $(\mathrm{T})$, Subtropical sites $(\mathrm{ST})$.

The altitude ranged from 36 to 926 meters regarding the sea level, presenting an average of 619 meters (e.g TECHS 12 as the lower altitude site, near the Brazilian coast, e.g TECHS 26 as the higher altitude site).

In this way, a wide variety of climates, altitudes, temperature, and orders of soils may be perceived (Table 3 and Figure 1). This may lead to confusion between different climates and soils, for example, to compare soils and productivity in an extremely water-restrictive environment (e.g TECHS 26 in Table 2) with climates, water surpluses and consequently higher productivity (e.g TECHS 22 in Table 2). Thus, the clustering of the sites according to the climatic classification proposed by Koppen (KOPPEN, 1936) and the Aridity Index was performed to avoid comparisons of soils of very different climatically sites, which would not make sense.

Soil collections occurred before the experiment installation between the years 2011 and the beginning of 2012 before the preparation of the soil and to generate the fertilization recommendation of the experiments. All the plots were fertilized intensively during the first year $\left(70 \mathrm{~kg} \mathrm{~N} \mathrm{ha}^{-1}, 45 \mathrm{~kg} \mathrm{P} \mathrm{ha}^{-1}, 85 \mathrm{~kg} \mathrm{~K} \mathrm{ha}^{-1}, 500 \mathrm{~kg} \mathrm{Ca} \mathrm{ha}{ }^{-1}, 90 \mathrm{~kg} \mathrm{Mg} \mathrm{ha}{ }^{-1}, 40 \mathrm{~kg} \mathrm{~S} \mathrm{ha}^{-1}, 3 \mathrm{~kg} \mathrm{~B} \mathrm{ha}{ }^{-1}, 1 \mathrm{~kg}\right.$ $\mathrm{Cu} \mathrm{ha} \mathrm{C}^{-1}$, and $1 \mathrm{~kg} \mathrm{Zn} \mathrm{ha}^{-1}$ ) to relieve any nutrient limitation. The schedule of fertilizer application varied among sites, with the total application divided between 2-4 applications from the preplanting through 12 months. Herbicides were used to keep the plots weed-free.

Holloway and Stork (1991) suggest that the ideal soil attributes to study cause-effect relationships with productivity should provide immediate and accurate responses to soil fertility, several attributes are desirable to ensure good interpretations. As well as having ecological relevance, and are sensitive to long-term variations, but on the other hand, resistant to shortterm variations such as changes in the atmospheric conditions and also in the evolution of culture in question. Among all the attributes presented, it was chosen to study the relationships between soil productivity and soil variables only influenced by management and fertilization after planting: organic matter (O.M.), Cation Exchange Capacity (CEC) and granulometry (Clay, Silt and Sand), because they are important attributes for the soil quality (HOLLOWAY; STORK, 1991).

The standards measure include growth in DBH and Height of 80 trees for each plot, measured every 6 months after the first year of planting. Each company was responsible for 
these measurements after standardization training through the measurement protocol. For the calculation of the commercial volume with bark (CVWB), volumetric models were used based on generic and widely used volume equations in Brazil calibrated for Eucalyptus sp. for the same planting density in the TECHS. All evaluations of this work occurred in the measurement performed on the birthdays of the 4 th-year-old of the experiments, but the ages ranged from 46 to 53 months old, with an average of 50.3 months of age.

From the volumetric data, the Dry Response (DR) was calculated for each clone in each experiment considering the equation below:

$$
D R=\frac{C V W B w / o .-C V W B w}{C V W B w / o} * 100
$$

Wherein:

$\mathrm{DR}=$ dry response $(\%)$

CVWB w/o.= commercial volume with bark without rain exclusion.

CVWB w. = commercial volume with bark excluding rain.

To determine the determinant attributes of productivity, we used Pearson's correlation coefficient ( $r$ ) for each aridity class.

\section{Results and discussion}

The coefficient of variation between the CVWBs of the clones ranged from $34 \%$ to $51 \%$ (Table 4). For DR, they ranged from $55 \%$ to $75 \%$. For the A1 clone, the coefficient of variation $(\mathrm{CV})$ for the CVWB variable presented may be considered low or regular, whereas, for the other clones, the coefficients of variation are classified as high. This reaffirms the presence of interaction genotype $\mathrm{x}$ environments, and automatically shows that clones behave are quite different according to the environmental conditions, but there are more plastic clones than others. However, A1 clone presented lower CV for CVWB, and on the other hand, higher coefficients of variation for DR. This clearly shows the dilemma between increased productivity and often plasticity and dry tolerance (HAKAMADA et al., 2017).

Table 4 - Descriptive statistics of the plant attributes and soil physical-chemical attributes (depth 0-40 cm) of the evaluated sites in the TECHS

Tabela 4 - Estatística descritiva dos atributos das plantas e atributos físico-químicos (profundidade $0-40 \mathrm{~cm}$ ) dos solos dos sítios avaliados no TECHS

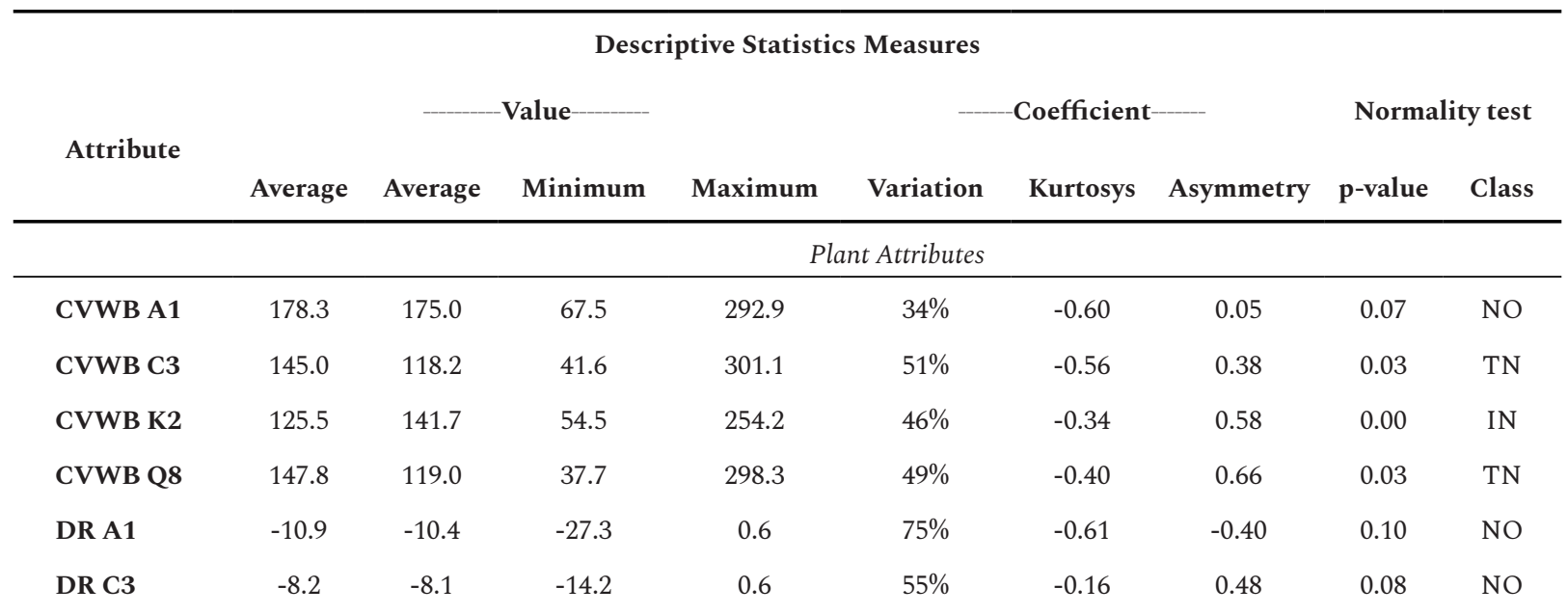


Table 4 - Conclusion ...

Tabela 4 - Conclusão ...

\begin{tabular}{|c|c|c|c|c|c|c|c|c|c|}
\hline \multirow{3}{*}{ Attribute } & \multirow{2}{*}{\multicolumn{7}{|c|}{ Descriptive Statistics Measures }} & \multirow{2}{*}{\multicolumn{2}{|c|}{ Normality test }} \\
\hline & & & & & & & & & \\
\hline & Average & Average & Malue- & Maximum & Variation & Kurtosys & Asymmetry & p-value & Class \\
\hline & \multicolumn{9}{|c|}{ Plant Attributes } \\
\hline DR K2 & -13.9 & -16.6 & -24.9 & 1.1 & $58 \%$ & -0.93 & 0.29 & 0.06 & NO \\
\hline \multirow[t]{2}{*}{ DR Q8 } & -13.9 & -14.1 & -25.9 & -1.1 & $64 \%$ & -1.31 & 0.04 & 0.21 & $\mathrm{NO}$ \\
\hline & \multicolumn{9}{|c|}{ Soil Attributes } \\
\hline pH & 4.06 & 4.02 & 3.71 & 5.04 & $6 \%$ & 3.5 & 1.6 & 0.00 & IN \\
\hline O.M. & 28.90 & 28.50 & 6.00 & 71.00 & $55 \%$ & -0.3 & 0.6 & 0.01 & IN \\
\hline $\mathbf{P}$ & 1.98 & 1.00 & 0.00 & 17.00 & $143 \%$ & 16.7 & 3.5 & 0.17 & NO \\
\hline $\mathbf{K}$ & 2.59 & 1.50 & 0.20 & 8.20 & $87 \%$ & -0.2 & 1.0 & 0.07 & NO \\
\hline $\mathrm{Ca}$ & 22.08 & 12.50 & 1.00 & 73.00 & $102 \%$ & -0.1 & 1.0 & 0.07 & NO \\
\hline Mg & 5.65 & 3.00 & 1.00 & 28.00 & $122 \%$ & 3.9 & 2.1 & 0.03 & $\mathrm{TN}$ \\
\hline Al & 14.23 & 8.55 & 0.80 & 68.30 & $106 \%$ & 7.7 & 2.7 & 0.03 & $\mathrm{TN}$ \\
\hline $\mathbf{H}+\mathbf{A l}$ & 81.27 & 64.00 & 16.00 & 267.00 & $79 \%$ & 2.1 & 1.5 & 0.01 & IN \\
\hline SB & 30.84 & 25.65 & 2.40 & 89.70 & $93 \%$ & -0.6 & 0.8 & 0.11 & $\mathrm{NO}$ \\
\hline CEC & 112.11 & 84.35 & 29.30 & 342.70 & $68 \%$ & 2.4 & 1.7 & 0.07 & NO \\
\hline V & 28.58 & 25.00 & 2.00 & 85.00 & $83 \%$ & -0.4 & 0.8 & 0.20 & NO \\
\hline $\mathbf{m}$ & 39.77 & 35.50 & 1.00 & 91.00 & $66 \%$ & -1.0 & 0.4 & 0.00 & IN \\
\hline$S$ & 11.50 & 10.67 & 1.00 & 39.00 & $85 \%$ & -0.1 & 0.8 & 0.00 & IN \\
\hline $\mathrm{Cu}$ & 0.78 & 0.44 & 0.08 & 5.56 & $137 \%$ & 15.2 & 3.8 & 0.00 & IN \\
\hline Zn & 0.35 & 0.29 & 0.10 & 1.22 & $73 \%$ & 2.8 & 1.7 & 0.37 & NO \\
\hline Mn & 3.65 & 1.53 & 0.06 & 31.80 & $153 \%$ & 13.6 & 3.3 & 0.04 & $\mathrm{TN}$ \\
\hline $\mathbf{F e}$ & 59.88 & 49.00 & 8.60 & 191.00 & $68 \%$ & 1.2 & 1.1 & 0.00 & IN \\
\hline B & 0.13 & 0.12 & 0.01 & 0.27 & $65 \%$ & -1.2 & 0.1 & 0.00 & IN \\
\hline Clay & 338.9 & 302.0 & 62.5 & 801.5 & $69 \%$ & -1.0 & 0.5 & 0.01 & IN \\
\hline Silt & 123.2 & 96.4 & 28.4 & 292.0 & $56 \%$ & -0.5 & 0.7 & 0.02 & IN \\
\hline Sand & 538.0 & 588.3 & 70.0 & 896.5 & $52 \%$ & -1.4 & -0.3 & 0.00 & IN \\
\hline
\end{tabular}

Source: Authors (2018)

On what: CVWB = Commercial Volume With Bark of Clones (A1, C3, K2, Q8) in $\mathrm{m}^{3} \mathrm{ha}^{-1}$; DR = Dry Response (\%); $\mathrm{pH}=$ hydrogen potential, O.M. = organic matter $\left(\mathrm{g} \mathrm{dm}^{-3}\right), \mathrm{P}=$ phosphorus in soil $\left(\mathrm{mg} \mathrm{dm}^{-3}\right), \mathrm{K}=$ potassium in soil $\left(\mathrm{mmol}_{\mathrm{c}} \mathrm{dm}^{-3}\right)$, $\mathrm{Ca}=$ calcium in soil $\left(\mathrm{mmol}_{\mathrm{c}} \mathrm{dm}^{-3}\right), \mathrm{Mg}=$ magnesium in soil $\left(\mathrm{mmol}_{\mathrm{c}} \mathrm{dm}^{-3}\right), \mathrm{Al}=$ aluminum $\left(\mathrm{mmol}_{\mathrm{c}} \mathrm{dm}^{-3}\right), \mathrm{H}+\mathrm{Al}=$ potential acidity $\left(\mathrm{mmol}_{\mathrm{c}} \mathrm{dm}^{-3}\right), \mathrm{SB}=$ Exchangeable base sum $\left(\mathrm{mmol}_{\mathrm{c}} \mathrm{dm}^{-3}\right) ; \mathrm{CEC}=$ cation exchange capacity $\left(\mathrm{mmol}_{\mathrm{c}} \mathrm{dm}^{-3}\right) ; \mathrm{V}=\mathrm{base}^{-}$ saturation (\%); $\mathrm{m}$ = saturation by aluminum (\%); $\mathrm{S}=$ sulfur content in the soil $\left(\mathrm{mg} \mathrm{dm}^{-3}\right)$; $\mathrm{Cu}=$ copper content in the soil $\left(\mathrm{mg} \mathrm{dm}^{-3}\right) ; \mathrm{Zn}=$ zinc content in the soil $\left(\mathrm{mg} \mathrm{dm}^{-3}\right) ; \mathrm{Mn}=$ manganese content in the soil $\left(\mathrm{mg} \mathrm{dm}^{-3}\right) ; \mathrm{Fe}=$ iron content in the soil $\left(\mathrm{mg} \mathrm{dm}^{-3}\right) ; \mathrm{B}=$ boron content in the soil $\left(\mathrm{mg} \mathrm{dm}^{-3}\right)$; Clay = clay texture $\left(\mathrm{g} \mathrm{kg}^{-1}\right)$; Silt = silt texture $\left(\mathrm{g} \mathrm{kg}^{-1}\right)$; Sand $=$ sand texture $\left(\mathrm{g} \mathrm{kg}^{-1}\right)$. $\mathrm{NO}=$ normal data distribution; $\mathrm{TN}=$ tending to the normal distribution; $\mathrm{IN}=$ distribution of Undetermined data. 
Another point to be considered is the fact that the reduction of $30 \%$ of the rainfall, reduced the CVWB or the DR between -8.2 and $13.9 \%$ of CVWB (Table 4), and it is, therefore, not proportional to the relation between the rainfall reduction and the eucalypts productivity. Stape et al. (2010) reported that irrigation increase the Eucalyptus sp. growth by about $30 \%$ and that the water is a major limiting factor for productivity in Brazil (productivity from $46 \mathrm{~m}^{-3} \mathrm{ha}^{-1}$ year $^{-1}$ to $62 \mathrm{~m}^{-3} \mathrm{ha}^{-1}$ year $^{-1}$ ). Araujo (2010) reported that irrigated eucalyptus in the Aquidauana region (MS) had productivity $41 \%$ above the rainfall conditions, and that to make the irrigation an irrigation system feasible, productivity should be higher than the rainfall conditions. Obviously, the goal of the TECHS was to evaluate or simulate a drought situation, and it may be observed that trees have very efficient ecophysiological mechanisms, in which even water being the predominant factor for growth (STAPE et al., 2010), it is not the only factor, and the integration of production factors is more important.

Still in this context, and abstracting the reasoning for physiological questions, it has been that the growth occurs basically by the interaction or the ability of the plants/trees to use the growth factors as: water, light, and nutrients, especially for the Eucalyptus crop, the water factor is dominant (STAPE et al., 2010). Therefore, the main organs of the plant responsible for growth would be the Eucalyptus roots, responsible for water absorption; and the stomata, which are responsible for the osmotic regulation and $\mathrm{CO}_{2}$ inputs, for use in photosynthesis (TAIZ; ZEIGER, 2002). Many hypotheses for mechanisms causing disability mortality are currently discussed, among which cavitation and carbon formation have been the focus of many research, although additional mechanisms of carbon immobilization and transport failure may also occur (SALA; PIPER; HOCH, 2010).

Negative asymmetry coefficients suggest the trend of data concentration on the left of the average of the samples, whereas positive coefficients suggest a concentration of the data on the right of the data samples. Generally, the coefficient of asymmetry above the unit means the existence of outliers in the data set, which is strongly influenced by extreme values concerning the sample set, which generates the need for treatments of the same, as observed in Copper with an asymmetry coefficient of 3.8. These coefficients disagree with the study carried out by Carvalho et al. (2012), and the other data are within the patterns of the asymmetry coefficients presented in other studies in Brazil (GONÇALVES et al., 2012).

It is understood as advisable to publish all attributes of the soil, raised during the initial collection of the TECHS soils, but as some chemical attributes of the soils, such as: $\mathrm{P}, \mathrm{K}, \mathrm{Ca}, \mathrm{Mg}$, ranged according to the management, and for the selection of the attributes considered stable in the soils (ROSSET; SCHIAVOAND; ATANÁZIO, 2014), such as O.M., CEC, Clay, Silt, and Sand.

According to the criteria established by Raij et al. (1996), and Ribeiro, Guimarães and Venegas (1999) the average values of the soil attributes ranged from very high (CEC, Fe), high (Ca, S), medium (O.M., K, Mg, Al, Cu, Mn, H+Al), low (m, Zn, B), very low (pH, P, SB, V). However, the analysis shows that the coefficients of variation ranged from $1.22 \%$ for soil zinc contents to $342 \%$ for CEC values, which should be weighted in the above interpretations (Table 4).

According to the criteria established by EMBRAPA (2006), the texture of the soils of the TECHS was classified as average texture ( $340 \mathrm{~g} \mathrm{~kg}^{-1}$ clay, $120 \mathrm{~g} \mathrm{~kg}^{-1}$ silt, $540 \mathrm{~g} \mathrm{~kg}^{-1}$ sand). However, the texture varied from sandy to very clayey, being silt the only texture class not observed.

The very low $\mathrm{pH}$ contributed to the lower availability of nutrients to plants, especially $\mathrm{P}$ and micronutrients, in addition to conditioning $\mathrm{Al}$, with medium contents tending to high, since this element ends up being preferentially adsorbed to other ions, such as calcium, magnesium, and potassium, which are indispensable to the nutrition of forest stand (DECHEN; NACHTIGALL, 2007). However, aluminum is not limiting to the growth of Eucalyptus, since species of the genus are highly tolerant to the expressive presence of this element in the soil (NEVES; NOVAIS; BARROS, 1982). 
The average O.M. content was strongly influenced by the higher extreme values, such as sites in southern Brazil and those located in regions of the Atlantic Forest, such as site 22 (Tables 2 and 3). It may be considered, that one of the factors that contributed to O.M. is the fact that forest ecosystems are considered conservative in terms of O.M. through the biogeochemical cycling of eucalyptus plantations. That the deep leaching of nutrients occurs in a little expressive way, including the most mobile nutrients in soils, $\mathrm{N}$ and K (LACLAU et al., 2010), and which end up being stored in O.M., which will be considered in the nutrient balance of subsequent cycles.

Generally, soils with a silty texture are Cambisols that cover the order of mineral soils with very variable characteristics, but always with medium or finer texture and absence of great pedogenetic development. They are soils with lower depth, high content of primary minerals (minerals inherited from the rock), a significant presence of rock fragments in the soil mass and other indications of incipient soil weathering (EMBRAPA, 2006). According to Laclau et al. (2013), the fine roots of eucalyptus develop deeply and are strongly responsible for the absorption of nutrients and water in-depth and, therefore, the Cambisols are not suitable soils for eucalyptus plantations, or they have little aptitude for the cultivation of this species.

The average productivity of CVWB was $149.1 \mathrm{~m}^{-3} \mathrm{ha}^{-1}$, ranging from 125.5 to $178.3 \mathrm{~m}^{3} \mathrm{ha}^{-1}$ among the most and least productive clones, being these values close to the national average of forest productivity (INDÚSTRIA BRASILEIRA DE ÁRVORES, 2015). Sustaining or increasing the high rates of Eucalyptus growth depends on a variety of changes in the future. Annual variations in the precipitation may alter gross primary production and wood production by onethird to one-half, and any regional changes in climate would likely result in regional changes in production (STAPE; BINKLEY; RYAN, 2008).

The CVWB strongly correlated in the Sub-Humid climate with the Sand, and to a weaker extent with clay and silt; already for DR correlated strongly with the independent variable CEC (Table 5). For sites located in the Wet Aridity class, CVWB strongly negatively correlated with O.M. and clay, and positively with the sand. For DR, the correlations were observed for the SubHumid climate for the CEC and Sand variables, and for the Humid Climate, no correlations were observed between the soil attributes with DR.

Table 5 - Pearson's linear correlation coefficient values for the soil attributes studied as a function of the aridity class for the TECHS sites

Tabela 5 - Valores do coeficiente de correlação linear de Pearson para os atributos do solo estudados em função da classe de aridez para os sítios do TECHS

\begin{tabular}{lccccc}
\hline \multirow{1}{*}{ Parameter } & O.M. & CEC & Clay & Silt & Sand \\
\cline { 2 - 5 } Class of aridity & & & Sub-Humid $^{1}$ & & \\
\hline CVWB A1 & $0.06^{\text {n.s }}$ & $-0.40^{\text {n.s }}$ & $0.46^{*}$ & $0.27^{\text {n.s }}$ & $-0.66^{\text {n.s }}$ \\
CVWB C3 & $0.11^{\text {n.s }}$ & $-0.08^{\text {n.s }}$ & $0.30^{\text {n.s }}$ & $0.24^{\text {n.s }}$ & $-0.46^{\text {n.s }}$ \\
CVWB K2 & $-0.15^{\text {n.s }}$ & $-0.24^{\text {n.s }}$ & $0.20^{\text {n.s }}$ & $0.47^{*}$ & $-0.45^{*}$ \\
CVWB Q8 & $0.13^{\text {n.s }}$ & $0.11^{\text {n.s }}$ & $0.30^{\text {n.s }}$ & $0.17^{\text {n.s }}$ & $-0.43^{\text {n.s }}$ \\
CVWB avr. & $0.03^{\text {n.s }}$ & $-0.17^{\text {n.s }}$ & $0.34^{\text {n.s }}$ & $0.30^{\text {n.s }}$ & $-0.54^{*}$ \\
DR avr. & $-0.16^{\text {n.s }}$ & $0.68^{*}$ & $-0.34^{\text {n.s }}$ & $0.02^{\text {n.s }}$ & $0.40^{*}$ \\
\hline
\end{tabular}


Table 5 - Conclusion ...

Tabela 5 - Conclusão ...

\begin{tabular}{|c|c|c|c|c|c|}
\hline Parameter & O.M. & CEC & Clay & Silt & Sand \\
\hline Class of aridity & & & Humid $^{2}$ & & \\
\hline CVWB A1 & $-0.50^{\mathrm{n} . \mathrm{s}}$ & $-0.16^{\text {n.s }}$ & $-0.62 *$ & $-0.41^{\mathrm{n} . \mathrm{s}}$ & 0.63 * \\
\hline CVWB C3 & $-0.35^{\mathrm{n} . \mathrm{s}}$ & $0.12^{\text {n.s }}$ & $-0.48^{\mathrm{n} . \mathrm{s}}$ & $-0.32^{\mathrm{n} . \mathrm{s}}$ & $0.49^{\text {n.s }}$ \\
\hline CVWB K2 & $-0.36^{\mathrm{n} . \mathrm{s}}$ & $-0.25^{\mathrm{n} . \mathrm{s}}$ & -0.58 * & $-0.02^{\mathrm{n} . \mathrm{s}}$ & 0.53 * \\
\hline CVWB Q8 & $-0.52^{\mathrm{n} . \mathrm{s}}$ & $0.03^{\mathrm{n} . \mathrm{s}}$ & -0.72 * & $-0.28^{\mathrm{n} . \mathrm{s}}$ & 0.70 * \\
\hline CVWB avr. & -0.59 * & $-0.14^{\text {n.s }}$ & $-0.82 *$ & $-0.31^{\mathrm{n} . \mathrm{s}}$ & 0.79 * \\
\hline DR avr. & $0.24^{\text {n.s }}$ & $-0.19^{\text {n.s }}$ & $0.31^{\mathrm{n} . \mathrm{s}}$ & $-0.26^{\mathrm{n} . \mathrm{s}}$ & $-0.25^{\text {n.s }}$ \\
\hline
\end{tabular}

Source: Authors (2018)

On what: CVWB A1, C3, K2, Q8 = trade volume with bark average of each TECHS clone. CVWB avr. = trade volume with bark average of the 4 TECHS plastic clones. DR avr. = average dry response of 4 plastic clones in TECHS. O.M. = organic matter of the soil; CEC = cation exchange capacity. Clay = clay texture of the soil. Silt $=$ silt texture of the soil. Sand $=$ sand texture of the soil. ${ }^{1}$ Correlations obtained with 11 sites located in Sub-Humid aridity classes; ${ }^{2}$ Correlation obtained with 7 sites located in the Wet aridity classes. ${ }^{*}$ Significant at $95 \%$ probability; n.s not significant.

The positive correlations with the CEC, Clay, and Silt variables were also highlighted in Table 5 of the Sub-Humid climate, while for the Humid Climate, Clay was negatively correlated with CVWB. In parts, this can be explained by the fact that the soil attributes in the aridity classes of the Sub-Humid sites have smaller water supply and small variations in the clay contents amplify or dampen the drought more strongly than in the Wet Aridity classes. Gava and Gonçalves (2008) reported that eucalyptus productivity reached its maximum potential between 350 and $400 \mathrm{~g} \mathrm{~kg}^{-}$ ${ }^{1}$, and then tended to stabilize. However, these authors evaluated this behavior only in one type of climate and in relatively close areas. This can be explained by completely different physical factors of soils that are easily explained in pedogenetic terms: 1) Eucalyptus productivity increases with increasing clay content to the point where oxygen saturation is optimal and water supply is maintained under adequate conditions (GAVA; GONÇALVES, 2008; STAPE et al., 2010); 2) from the point where the soil is saturated with water and added to this, the oxygen saturation point becomes low, especially for several periods of time, the yield is negatively affected (PAULA et al., 2012). On the other hand, it is also considered that as the water supply is higher in the sites of the Wetness classes, Clay becomes a reducing productivity factor due to its higher moisture retention capacity, and consequently, lower soil aeration (BREEMEN; BUURMAN, 1998), which may lead to chronic hypoxia for the forest plantations in these regions.

Still in this context, and abstracting the reasoning for physiological questions, it has been that the growth occurs basically by the interaction or the ability of the plants/trees to use the growth factors, water, light, and nutrients, especially for the Eucalyptus crop, the water factor is dominant (STAPE et al., 2010). Therefore, the main responsible organs of the plant for growth would be the roots of the Eucalyptus, responsible for water absorption; and the stomata, which are responsible for osmotic regulation and $\mathrm{CO}_{2}$ inputs, for use in photosynthesis (TAIZ; ZEIGER, 2002). Many hypotheses for mechanisms causing disability mortality are currently discussed, among which cavitation and carbon formation have been the focus of many research, although additional mechanisms of carbon immobilization and transport failure may also occur (MCDOWELL, 2011).

These data agree with those obtained by Zeppel, Adams and Anderegg (2011), where mortality probably occurs due to reductions in precipitation and increases in temperatures and 
vapor pressure deficits (VPD), leading to a greater soil moisture deficiency and/or increased atmospheric water demand (MCDOWELL, 2011) in the most arid regions of forest plantations.

The DR showed a significant and positive correlation with CEC $(\mathrm{R}=0.68, \mathrm{p}<0.05)$ and Sand $(\mathrm{R}=0.40, \mathrm{p}<0.05)$ in the Sub-Humid climate, while were not observed significant correlations in the humid climate (Table 5). This is an obvious way to show that the climate stratification performed in this paper has been able to capture the limitation of water in the humid climate and the large water supply in the humid climate.

In the case of the Sub-Humid climate, it has as one of the main characteristics, a welldefined dry season (Brazilian Cerrado), it may be said that some characteristics of the trees make the plants to lose productivity: 1) During the drought, plants of all species closed stomata in response to decreased soil's water potential, but some conifer species avoid the water potentials associated with xylem embolism, as a result of early stomatal closure in relation to thresholds of hydraulic dysfunction (BLACKMAN et al., 2019); 2) During drought, trees tend to lose leaves to prevent evapotranspiration (ZEPPEL; ADAMS; ANDEREGG, 2011). Recent work has shown that the time plants took to reach critical levels of water stress during final drying was similar between angiosperms (ranging from 39 to 57 days) and longer in conifers (156 days) (BLACKMAN et al., 2019). These same authors report that the drying time of the plant was influenced by several factors, including the stomatal-hydraulic safety margin of the species, as well as leaf succulence and minimal stomatal conductance.

\section{Conclusions}

It can be concluded that the attribute of the soil that most affects the productivity depends strongly on climate, and in Sub-Humid climates, clay contributes positively to the increase of productivity, while in Humid climates, the opposite occurs, just as productivity response to drought (DR) also depends heavily on climate, effects of CEC and Sand are observed only in the Sub-Humid climate, which is where there is a well-defined dry season.

\section{Acknowledgments}

The TECHS Project relied on contributions from more than 150 people from 26 companies, and we thank everyone for their contributions to the Project. The project was financed by 26 companies with a principal researcher: Anglo American (Andre Machado), Arauco (Rodrigo Coutinho), Arborgen (Gabriela Bassa), ArcelorMittal (Roosevelt Almado), Cenibra (Fernando Leite), CMPC (Elias Araujo) (Ubirajara Oliveira), Copener (Jacyr Alves), Duratex (Raul Chaves), Eldorado (Vinicius Silva), Fazenda Campo Bom (Jacqueline Pirez), Fibria (Rodolfo Loos), Florestal Itaquari (Admir Mora), Forestal Oriental), Gerdau (Francisco Gomes), GMR (Paulo Leite), International Paper (Cristiane Lemos), Jari (Katia Silva), Klabin (James Stahl), Lwarcel (Marcela Capoani), Montes del Plata (Alejandro Gonzalez), Plantar (David Fernandes), Rigesa (Ricardo Paim), Suzano (Luiz Fabiano), Vallourec (Helder Andrade) and Veracel (Helton Lourenço). Fundamental assistance was provided to various aspects of the project by Luiz Barrichelo, Dario Grattaplagia, Mike Ryan, Eduardo Mattos, Robert Hubbard, Rodrigo Hakamada, Aurelio Aguiar, Leandro de Siqueira, Gleison dos Santos, and João Flavio Silva. The project also received support from these universities and institutes: University of São Paulo - Brazil, State University of São Paulo - Brazil, Federal University of Lavras - Brazil, Federal University of Rio Grande do Norte - Brazil, Colorado State University - USA, North Carolina State University - USA, USDA Forest Service, CNPq - Brazil and Fapesp - Brazil. 


\section{References}

ALVARES, C. A. et al. Köppen's climate classification map for Brazil. Meteorologische Zeitschrift, Stuttgart, v. 22, p. 711-728, 2013. doi: 10.1127/0941-2948/2013/0507.

ARAUJO, H. B. Avaliação econômica de Eucalipto irrigado em diferentes cenários. 2010. Tese (Doutorado em Agronomia - Irrigação e Drenagem) - Universidade Estadual Paulista, Botucatu, 2010.

ASSAD, E. D. et al. Impacto das mudanças climáticas no zoneamento agroclimático do café no Brasil. Pesquisa Agropecuária Brasileira, Brasília, v. 39, p. 1057-1064, 2004.

BINKLEY, D. et al. The interactions of climate, spacing, and genetics on clonal Eucalyptus plantations across Brazil and Uruguay. Forest Ecology and Management, Amsterdam, v. 405, p. 271-283, 2017. doi: http://dx.doi.org/10.1016/j.foreco.2017.09.050

BLACKMAN, C. J. et al. Drought response strategies and hydraulic traits contribute to the mechanistic understanding of plant dry-down to hydraulic failure, Tree Physiology, Oxford, v. 39, n. 6, p. 910-924, jun. 2019. doi.org/10.1093/treephys/tpz016

BREEMEN, N. V. ; BUURMAN, P. Soil formation. Dordrecht: Kluwer, 1998. 376 p.

CARVALHO, M. P. et al. Produtividade de madeira do eucalipto correlacionada com atributos do solo visando ao mapeamento de zonas especificas de manejo. Ciência Rural, Santa Maria, v. 42, n. 10, p. 1797-1803, 2012.

DECHEN, A. R.; NACHTIGALL, G. R. Elementos requeridos à nutrição de plantas. In: NOVAIS, R. F. et al. (ed.). Fertilidade do solo. Viçosa, MG: Sociedade Brasileira de Ciência do Solo, 2007. p. 91-132.

EMBRAPA. Centro Nacional de Pesquisa de Solos. Manual de métodos de análises de solo. Brasília: Embrapa Produção de Informação; Rio de Janeiro: EMBRAPA Solos, 1997.

EMBRAPA. Centro Nacional de Pesquisa de Solos. Sistema Brasileiro de Classificação de Solos. Brasília: EMBRAPA Produção de Informação; Rio de Janeiro: EMBRAPA Solos, 2006.

FLORES, T. B. et al. Eucalyptus no Brasil: zoneamento climático e guia para identificação. Piracicaba: IPEF, 2016. 448 p.

GAVA, J. L.; GONÇALVES, J. L. M. Soil attributes and Wood quality for pulp production in plantations of Eucalyptus grandis clone. Scientia Agrícola, Piracicaba, v. 65, n. 3, p. 306-313, maio/jun. 2008.

GONÇALVES, J. L. M. et al. Integrating genetic and silvicultural strategies to minimize abiotic and biotic constraints in Brazilian eucalypt plantations. Forest Ecology and Management, Amsterdam, v. 301, p. 6-27, 2013.

GONÇALVES, J. L. M. et al. Mapeamento de solos e da produtividade de plantações de Eucalyptus grandis em Itatinga, SP, com uso de sistema de informação geográfica. Scientia Foretalis, Piracicaba, v. 94, p. 187-201, 2012.

HAKAMADA, R. et al. Biomass production and potential water stress increase with planting density in four highly productive clonal Eucalyptus genotypes. Southern Forests: a Journal of Forest Science, Washington, v. 79, n. 3, p. 251-257, 2017. doi: 10.2989/20702620.2016.1256041

HOLLOWAY, J. D.; STORK, N. D. The dimensions of biodiversity: the use of invertebrates as indicator of human impact. In: HAWKSWORTH, D. L. The biodiversity of microorganisms and invertebrates: its role in sustainable agriculture. Wallingford: CAB International, 1991. p. 37-63.

INDÚSTRIA BRASILEIRA DE ÁRVORES. Brazilian Tree Industry Annual Report (2015). Brasília, DF, 2015. 77 p. 
KOPPEN, W. Das geographische System der Klimate. In: KOPPEN, W.; GEIGER, G. Handbuch der Klimatologie, Teil C. Berlin: Gebruder Bornträger, 1936. p. 1-44.

LACLAU, J.-P. Dynamics of soil exploration by fine roots down to a depth of $10 \mathrm{~m}$ throughout the entire rotation in Eucalyptus grandis plantations. Frontiers in Plant Science, Lausanne Switzerland, v. 4, p. 243-250, 2013. doi : http://doi.org/10.3389/fpls.2013.00243

LACLAU, J.-P. et al. Biogeochemical cycles of nutrients in tropical Eucalyptus plantations. main features shown by intensive monitoring in Congo and Brazil. Forest Ecology Management, Amsterdam, v. 259, p. 1771-1785, 2010. doi: https://doi.org/10.1016/j.foreco.2009.06.010

MCDOWELL, N. G. Mechanisms linking drought, hydraulics, carbon metabolism, and vegetation mortality. Plant Physiology, Oxford, v. 155, p. 1051-1059, 2011. doi: https://doi.org/10.1104/ pp.110.170704

NEVES, J. C. L.; NOVAIS, R. F.; BARROS, N. F. Effect of aluminum in nutrient solution on growth and nutrient uptake by Eucalyptus spp. Revista Árvore, Viçosa, MG, v. 6, p. 1-16, 1982.

PAULA, R. R. et al. Propriedades edáficas e desenvolvimento de eucalipto em topossequência na Flona Mário Xavier - RJ. Floresta e Ambiente, Seropédica, v. 16, p. 344-351, 2012.

PENMAN, H. L. The physical bases of irrigation control. In: HORTICULTURAL CONGRESS, 2., London, 1953. Proceedings [...]. London: [s. n.], 1953. p. 913-924.

QUAGGIO, J. A.; RAIJ, B. V.; MALAVOLTA, E. Alternative use of the SMP-buffer solution to determine limerequirement of soil. Comm. Soil Science and Plant Analysis, Philadelphia, v. 16, p. $245-260,1985$.

RAIJ, B. V. et al. Recomendações de adubação e calagem para o Estado de São Paulo. Campinas: Instituto Agronômico, 1996. 285 p. (Boletim técnico, 100).

RAIJ, B. V.; QUAGgiO, J. A.; CANTARELla, H. Análise química do solo para fins de fertilidade. Campinas, Fundação Cargil, 1987. 170 p.

RESENDE, M. D. V. et al. Genomic selection for growth and wood quality in Eucalyptus: capturing the missing heritability and accelerating breeding for complex traits in forest trees. New Phytologist, Oxford, v. 194, p. 116-128, 2012.

Ribeiro, C. A.; GUimarÃES, P. T. G.; VENEGAS, V. H. A. Recomendações para o uso de corretivos e fertilizantes em Minas Gerais - 5ª aproximação. Viçosa, MG: CFSEMG, 1999. 359 p.

ROSSET, J. S.; SCHIAVOAND, J. A.; ATANÁZIO, R. A. R. Chemical attributes, total organic carbon stock and humified fractions of organic matter soil submitted to different systems of sugarcane management. Ciências Agrárias, Londrina, v. 35, n. 5, p. 2351-2366, 2014. doi: http:// dx.doi.org/10.5433/1679-0359.2014v35n5p2351

SALA, A.; PIPER, F.; HOCH, G. Physiological mechanisms of drought induced tree mortality are far from being resolved. New Phytologist, Oxford, v. 186, p. 274-281, 2010. doi: 10.1111/j.14698137.2009.03167.x

SANTOS, H. G. et al. O novo mapa de solos do Brasil: legenda atualizada. 2. ed. Rio de Janeiro: EMBRAPA Solos, 2011. 67 p.

SILVA, F. R.; FERREIRA, F. F. Evaluation of boron extractors in soils of Ceará State, Brazil. Revista Brasileira de Ciência do Solo, Viçosa, MG, v. 22, p. 471-478, 1998.

SILVA, V. E. Atributos do solo e desenvolvimento radicular em plantações de eucalipto no Brasil. 2019. Tese (Doutorado em Agronomia - Sistemas de Produção) - Universidade Estadual Paulista, Ilha Solteira, 2019. 
STAPE, J. L. etal. The Brazil eucalyptus potential productivity project: influence of water, nutrients and stand uniformity on wood production. Forest Ecology and Management, Amsterdam, v. 259, n. 9, p. 1684-1694, 2010. doi: https://doi.org/10.1016/j.foreco.2010.01.012

STAPE, J. L.; BINKLEY, D.; RYAN, M. G. Production and carbon allocation in a clonal Eucalyptus plantation with water and nutrient manipulations. Forest Ecology and Management, Amsterdam, v. 255, p. 920-930, 2008.

STAPE, J. L.; RYAN, M. G.; BINKLEY, D. Testing the utility of the 3-PG model for growth of Eucalyptus grandis $\mathrm{X}$ urophylla with natural and manipulated supplies of water and nutrients. Forest Ecology and Management, Amsterdam, v. 193, p. 219-234, 2004. doi: 10.1016/j. foreco.2004.01.031

TAIZ, L.; ZEIGER, E. Plant physiology. 3th ed. Sunderland: Sinauer Associates, 2002. p. 423-460.

THORNTHWAITE, C. W. An approach toward a rational classification of climate. Geographical Review, New York, v. 38, p. 55-94, 1948.

VOLKOFF, B. et al. Landscape and soil regionalization in southern Brazilian Amazon and contiguous areas: methodology and relevance for ecological studies. Scientia Agricola, Piracicaba, v. 69, n. 3, p. 217-225, jun. 2012. doi: http://dx.doi.org/10.1590/S0103-90162012000300007.

ZEPPEL, M. J. B.; ADAMS, H. D.; ANDEREGG, W. R. L. Mechanistic causes of tree drought mortality: recent results, unresolved questions and future research needs. New Phytologist, Hoboken, v. 192, n. 4, p. 800-803, 2011. doi: 10.1111/j.1469-8137.2011.03960.x. 